technical difficulties by ignoring the fundamental problem, fortunately no longer appears. Still, Article 3 of the Code would be considerably stronger if its drafters had succeeded in the not too difficult task of defining rules which would offer needed protection, in the form of certainty, both to the bank and to legitimate adverse claimants.

is appointed by a court of competent jurisdiction to succeed to the customer's rights in the account." American Law Institute, National Conference of Commissioners on Uniform State Law, May 1949 Draft Uniform Commercial Code \& 3-640 (May, 1949).

\title{
JUDICIAL INNOVATIONS IN THE NEW YORK ARBITRATION LAW
}

The New York arbitration law appears to be undergoing gradual revision by judicial interpretation. Recent New York law reports show a trend toward narrowing the arbitrator's function by enlarging the jurisdiction of the courts in several areas of arbitration law. Thus, in the field of labor arbitration the courts have for some time construed their power to determine whether the parties have agreed to arbitrate to include the power to determine whether there is an arbitrable dispute. In the recent case of Alpert v. Admiration Knitzear Co. ${ }^{1}$ this rule was carried over into the field of commercial arbitration as well.

In the Alpert case the contract of sale contained the following provision: "[ $\mathrm{I} f \mathrm{f}$ at any time, in the sole opinion of the Seller, the financial responsibility of the Purchaser shall become impaired or unsatisfactory to the Seller cash payments in advance of delivery may be required." Failure of the buyer to pay any amount due gave the seller the right to terminate the contract. When the purchaser failed to comply with a demand for advance payment under this clause, the seller terminated. The buyer moved under $\S 1450$ of the New York arbitration statute $^{3}$ to compel arbitration according to an arbitration clause in the contract. The purchaser claimed that in commercial understanding the seller's right to demand advance payment was conditioned upon reasonable apprehension as to the purchaser's financial responsibility. While the arbitration clause provided that "[a]ny complaint, controversy or question which may arise with respect to this contract that cannot be settled by the parties thereto, shall be referred to arbitration. ..."4 the court said it was plain that there could be no dispute as to the meaning of the acceleration clause; according to the plain language of the contract, the seller had an unconditional right to demand advance payment and non-compliance with such demand by the buyer gave the seller the right to terminate the contract. The court held that as there was nothing for the arbitrators to decide, the motion should be denied.

2304 N.Y. 1, 105 N.E. 2d 561 (1952). 2 Ibid., at 4 and 562.

${ }^{3}$ N.Y. Civ. Practice Act (Thompson, 1939) $\$ \$ 1448-69$.

4304 N.Y. 1, 5, 105 N.E. 2d 561, 563 (1952). 
This result is clearly contrary to the meaning of the arbitration statute as interpreted by earlier New York cases. The statute has generally been considered a model arbitration statute, and in the years following its adoption in 1920when such great commercial judges as Cardozo, Crane, and Lehman were on the Court of Appeals-it was the expressed policy of the courts to favor arbitration. The duty of the court was held to be to enforce the agreement to arbitrate rather than to undertake itself to settle the dispute or to narrow the field of arbitrable disputes. ${ }^{5}$ The New York arbitration statute provides that on motion to compel or to stay arbitration the courts "shall hear the parties and upon being satisfied that there is no substantial issue as to the making of the contract [to arbitrate] or submission or the failure to comply therewith ... shall make an order directing the parties to proceed to arbitration in accordance with the terms of the contract." Under this provision the courts have until recently limited their function to interpreting the arbitration agreement, ${ }^{7}$ leaving the other terms of the contract to the arbitrator unless it was found that the parties had not agreed to arbitrate the issue in question. Thus, in an early case under the New York statute, Smith Fireproof Const. Co. v. Thompson-Starrett Co. ${ }^{8}$ where the arbitration clause in an agreement between a building contractor and his sub-contractor read, "In case the parties hereto disagree in relation to any clause in the contract, the question shall be referred to a Board of Arbitration...." and where the sub-contractor alleged that he had been damaged by the contractor's delay in performance, the Court of Appeals held the arbitration clause inapplicable since the controversy did not involve any particular clause in the contract. A stay of arbitration was granted. The difference is apparent between the two typical arbitration clauses in the Alpert and Smith cases. Under the provision in the Smith case the jurisdiction of the arbitrator is narrowly defined as extending only to "dispute[s] as to the meaning of any clause in [the] agreement. ..." On the other hand, the arbitration clause in the Alpert case covers "any complaint, controversy or question which may arise with respect to [the] contract...." Thus, under the broader clause a number of New York cases have sent to arbitration even claims of latent defects and issues of good faith. ${ }^{10}$ Since it was assumed that the arbitrators would construe the contract in accordance with the law, for "errors of law or judgment were not to be presumed," the courts were

5 Berkovitz v. Arbib \& Houlberg, Inc., 230 N.Y. 261, 130 N.E. 288 (1921).

See note 3 supra.

7 Tarello v. John A. Johnson Contracting Co., 50 N.Y.S. 2d 212 (S. Ct., 1944), aff'd 268 App. Div. 893, 51 N.Y.S. 2d 87 (1st Dep't, 1944).

8247 N.Y. 277, 160 N.E. 369 (1928).

Ibid., at 279 and 370.

${ }^{10}$ Tuttman v. Kattent, Talmas Export Corp, 274 App. Div. 395, 83 N.Y.S. 2d 651 (1st Dep't, 1948); Compagnie Francaise Des Petroles v. Pantepec Oil Co., 305 N.Y. 558, 111 N.E. 2d 645 (1953); Raphael v. Silberberg, 274 App. Div. 625, 86 N.Y.S. 2d 421 (1st Dep't, 1949).

1150 N.Y.S. 2d 212, 215 (S. Ct., 1944). It should be noted that the courts have little possibility of determining the reasons for the arbitrator's decision, since in most instances there is no record of what went on in the arbitral tribunal. 
hesitant to interfere and to stamp their own interpretation on the contract. At the same time the power of the courts to review the arbitrator's decision was narrowly construed.12

Within the last few years the courts have broadened their powers of review, and there has developed a new, narrowly limited concept of the functions of the arbitrator. The presumption that he follows the law has lost much of its force, and today the New York courts suspiciously check the results of arbitration. ${ }^{13}$ The jurisdiction of the arbitrator has been limited in three ways: First, extension by the courts of their scope of review. Second, usurpation by the courts of the arbitrator's function of determining the commercial reasonableness of arbitration clauses. Third, the erection of the doctrine that the courts must determine that there is an arbitrable dispute before the controversy may go to arbitration.

Western Union Tel. Co. v. American Comm. Ass' $n^{14}$ exemplifies the extension of the scope of judicial review. The controversy in the case arose out of a refusal by the union to handle "hot traffic"-cablegrams or telegrams which, at some point in their transmission, had been handled by a strike-bound company. The company and the union had adopted a collective bargaining agreement which provided "there shall be no strikes or other stoppages of work during the life of this contract" and, "[I]n the event that an agreement cannot be reached between the Union and the Company with respect to the application or interpretation of this contract ... such matters shall be submitted to an impartial arbitrator. ... The arbitrator shall not have the authority to alter or modify any of the express provisions of the contract."15 The arbitrator found that, "when read in the light of 'custom of trade' ... the work stoppage provision in the contract did not prohibit the union from directing employees not to handle such hot traffic or the employees from following such direction."16 The Court of Appeals affirmed an order by the Appellate Division which vacated the award. The court held that since the contract by its express words limited the jurisdiction of the arbitrator to "interpreting," not "changing" the contract, the arbitrator was not permitted to consider customs of the trade "where the language [of the contract] is unambiguous, the words plain and clear, conveying a distinct idea. ..." In such a case, said the Court of Appeals, "there is no occasion to resort to other means of interpretation."17 The case has been criticised on the ground that re-

12 See note 10 supra; consult 63 Harv. L. Rev. 681 (1950).

${ }^{13}$ Occasional statements are still to be found in the opinions indicating that the courts have not broadened their review power. See Matter of Allen, 279 App. Div. 444, 446-47, 110 N.Y.S. 2d 609, 610-12 (1st Dep't, 1952). But there can be no doubt that a court can find ways of circumventing an arbitration decision of which it does not approve. 63 Harv. L. Rev. 681 (1950). One method of achieving this is by means of the well established rule that it is the court's function (and not that of the arbitrators themselves) to determine the jurisdiction of the arbitrators. Western Union Tel. Co. v. American Comm. Ass'n, 299 N.Y. 177, 86 N.E. 2d 162 (1942). See also Unsinn v. Republique Francaise, 281 App. Div. 705, 117 N.Y.S. 2d 801 (2d Dep't, 1952).

14299 N.Y. 177, 86 N.E. 2d 162 (1942).

${ }^{15}$ Ibid., at 183 and 165.
${ }^{18}$ Ibid.

ir Tbid., at 185 and 166. 
quiring the arbitrator to conform to this customary rule of contract interpretation basically impairs the effectiveness of the arbitration proceeding. ${ }^{18}$

Matter of River Brand Rice Mills ${ }^{19}$ illustrates the second way in which the application of arbitration clauses has been limited. The provision in a contract of sale in that case read "Any controversy or claim arising out of or relating to this contract or the breach thereof shall be settled by arbitration. . . . Any demand for arbitration must be made within five days after tender." 20 Several weeks after the buyer had received and stored the merchandise under the contract, government inspectors found it contaminated and destroyed it. The purchaser then asked for reimbursement and the seller refused. Ten months later the purchaser moved to compel arbitration but the court granted a motion to stay, saying: "whatever meaning may reasonably be attributed to the word 'tender' it is clear that the demand for arbitration was not made within five days after such tender.'21 The buyer did not appeal from this decision; instead, he began an action at law. This action was also stayed under the Arbitration Act because the "plain meaning" of the arbitration clause was that all matters arising out of the contract were to be settled by arbitration. The court, however, went on to say: "It may be that, upon proper showing, the portion of the agreement containing the time limitation ... would be held to be so ambiguous or so unreasonably harsh, when applied to facts such as those presented here as to be unenforceable. That, however, was a matter to be determined when the seller sought originally to stay arbitration."22 Thus the case suggests that arbitration clauses will be interpreted by the court, at the time of a motion to stay, rather than by the arbitrator. ${ }^{28}$

The third aspect of this new policy toward arbitration is the doctrine expressed in the Alpert case that the courts, when considering a motion to compel or stay arbitration, are to pass on the question whether there is a real dispute to be decided by the arbitrators. While it has not been thus stated, this doctrine in essence enables the courts on motion to compel or stay arbitration to consider the merits of a controversy which the parties had originally agreed to submit to arbitration. It is merely necessary that one of the parties to the contract assert that there is in reality no dispute since the clause in controversy has only one possible interpretation. The courts seem increasingly willing, when the opportunity is thus presented, to keep the matter from going to arbitration by inter-

${ }^{18} \mathrm{Cox}$, The Place of Law in Labor Arbitration, 34 Chi. Bar Record 205, 210 (1953). Consult also 63 Harv. L. Rev. 347 (1949).

19305 N.Y. 36, 110 N.E. 2d 545 (1953).

${ }^{20}$ Ibid., at 37 and 546 (emphasis added).

21 Ibid., at 39 and 547. Ibid., at 41 and 549.

${ }^{23}$ The "all claims within $\mathrm{X}$ days" type of clause has been a device used by sellers with frequent success to avoid both arbitration and actions at law. While the Court of Appeals here hints that this result may no longer be expected, the solution suggested is not to send the clause to the arbitrators, but to have the parties fight their battle in court when a motion is made to compel or stay arbitration. 
preting the clause in question, or at least by saying that it needs no interpretation. The conclusion is frequently reached that the clause means "just what it says" and nothing more. The first clear pronouncement of the doctrine that the court is to determine the existence of a dispute was made in cases concerning labor arbitration. ${ }^{24}$ In the leading case, International Ass'n of Machinists v. Cutler-Hammer, ${ }^{25}$ the collective bargaining agreement between the parties contained a broad arbitration provision. The controversy concerned interpretation of a clause whereby the company agreed "to meet with the union ... to discuss payment of a bonus." ${ }^{26}$ The union urged that the clause required the company to make a reasonable effort to come to terms. The court, however, agreed with the employer's contention that to "discuss" a bonus meant to "talk" about it, not "to do something about it." "So clear is this," said the Supreme Court, "and so untenable any other interpretation, that we are obliged to hold that there is no dispute as to the meaning of the bonus provision. ..." ${ }^{27}$ The court held that since there was nothing to arbitrate, arbitration could not have been intended to extend to this clause. The Cutler-Hammer decision was affirmed without opinion by the Court of Appeals, two judges dissenting. ${ }^{28}$ The dissent was based on the argument that reasonable men could differ as to the meaning of the clause in question. "If there is a possibility of such a construction [as that which the union urged] the court should not remove the controversy from the sphere of arbitration, particularly when the applicable arbitration clause . . . is so broad. ${ }^{29}$ It should be noted that the court split here not in disagreement over the doctrine that a clause may be withheld from the arbitral tribunal if the court finds it unambiguous; it disagreed only on the question of the applicability of this doctrine to the situation before it. The Court of Appeals unanimously approved the Culler-Hammer innovation in a later case, General Electric Co. v. Uniled Electrical Radio, Machine Workers of America, CIO ${ }^{30}$ specifically holding it to be a question of law whether an arbitrable issue existed between the parties and that this question was to be determined by the courts. While this doctrine had perhaps been foreshadowed by dicta in earlier commercial cases, ${ }^{31}$ the Alpert decision is

${ }^{24}$ The Court of Appeals relied almost solely on these labor cases in the Alpert decision.

${ }^{25} 271$ App. Div. 917, 67 N.Y.S. 2d 317 (1st Dep't, 1947), aff'd without opinion, 297 N.Y. 519, 74 N.E. 2d 464 (1947).

${ }^{20} 271$ App. Div. 917, 918, 67 N.Y.S. 2d 317 (1st Dep't, 1947).

27 Ibid.

${ }^{28}$ See note 24 supra.

29297 N.Y. 519, 520, 74 N.E. 2d 464, 465 (1947).

30300 N.Y. 262, 90 N.E. $2 d 181$ (1949).

${ }_{81}$ Matter of Kramer, 288 N.Y. 467, 43 N.E. 2d 493 (1942). Here the OPA provided a price ceiling for cotton goods which lay below the contract price of an unexecuted contract for the sale of such goods. On petition to compel arbitration the court, Lehman dissenting, held that performance had been frustrated by the order and the contract thereby terminated. See also Matter of Gunze Silk Corp., 266 App. Div. 541, 43 N.Y.S. 2d 175 (1st Dep't, 1943). 
the first instance where it was plainly extended into the field of commercial arbitration by the Court of Appeals. ${ }^{22}$

Doubtless a "controversy" is required for arbitration, but it should be noted that the mere presence of the parties in court indicates a dispute of some sort. A New York court had previously called a dispute "a disagreement based on conflict of evidence or opinion. The term implies a situation in which something is asserted on one side and denied on the other." ${ }^{33}$ It cannot be denied that by such a test there was a dispute in the Alpert, Cutler-Hammer, and GE cases. In these cases the new judicial concept of arbitration is apparent. The parties had included the arbitration clause in their contract expecting that they were thus leaving the legal forum and the legal rules and were going to make their own law, or more correctly, to allow a third party to make it for them. The New York courts' position is that the parties cannot have this freedom under the statute.

The drastic decline in recent years of the number of commercial cases reaching the courts may be explained partly by the general prosperity prevalent during that period. But it is probable that this decline is also attributable to the increasing popularity of arbitration in the commercial world. The growing antipathy toward arbitration on the part of the New York courts may explain the uncommercial result in the Alpert decision. However, in Maller of Level Export Corp. ${ }^{34}$ decided several months after the Alpert case, the Court of Appeals seems to have deviated from this trend. In the Level Export case, where the agreement to arbitrate was incorporated into the sales-contract only by reference to the "Standard Cotton Textile Salesnote," the Court of Appeals denied a motion to stay arbitration. The trial court had found that the buyer was not acquainted with the "Salesnote" and upheld his contention that he had thus not agreed to arbitration. The Court of Appeals, however, reversed. It held that there existed no "substantial issue" whether the parties had agreed to arbitrate. Since the Court of Appeals was sine juris to disturb the specific findings of fact below, the Level Export case, though unlike the Alpert case in reaching a

while in the earlier case of Application of Brookside Mills, Inc., 94 N.Y.S. 2d 68, 69 (S. Ct., 1949), aff'd 276 App. Div. 357, 94 N.Y.S. 2d 509 (1st Dep't, 1950), the Appellate Division refused to send a controversy to arbitration on the same grounds, the decision was not cited in the Alpert case. In the Brookside Mills case the Supreme Court at Special Term explained its position by saying, "to permit arbitration as to respondents' right to resort to the collateral prior to the maturity date of the loan, would make it possible for the arbitrator to render an award directly contrary to the provisions of the agreements between the parties." This decision was affirmed on appeal, the court stating that "where the facts are defined and the legal conclusions to be drawn therefrom are well established, a party is not entitled to demand an arbitration in order that the law may be modified for his benefit merely because the contract contains an arbitration clause." 276 App. Div. 357, 364, 94 N.Y.S. 2d 509, 515 (1st Dep't, 1950). But cf. Matter of Roselle, 108 N.Y.S. 2d 921 (S. Ct., 1951).

${ }^{38}$ Webster v. Van Allen, 217 App. Div. 219, 221, 216 N.Y.S. 552, 555 (4th Dep't, 1926).

34305 N.Y. 82, 111 N.E. 2d 218 (1953). 
result favorable to arbitration, may be criticised as a commercial law precedent. ${ }^{35}$

On the other hand, an assumption that the results reached in the Alpert case and the other recent cases discussed above are incidents of the present trend away from arbitration leads to a reflection upon the policy underlying the arbitration law.

When the courts see no controversy in the "plain language" of the contract, they refuse to send the matter to arbitration because they fear that the arbitrator might decide in direct contradiction to the express contract terms. ${ }^{36}$ Parties cannot and evidently do not spell out every detail in their contracts; much is left to implication..$^{37}$ By refusing to go beyond the "plain meaning" of the express terms, the courts themselves interfere so as to make possible decisions in direct contradiction to these implied terms which the parties have agreed to arbitrate. Moreover, it should be noted that the courts do not hear all the evidence in proceedings to compel or stay arbitration of proceedings which presumably do not go to the merits of the controversy. The advantage which the arbitration procedure provides by disposing of controversies outside of the technical rules of law but in accordance with practical considerations of the transaction between the parties is largely limited by the courts' new policy toward arbitration. ${ }^{38}$ Under the Alpert rule, consideration of trade usage may be more greatly limited in arbitration cases than it is in ordinary commercial suits. At law, trade usage is an issue for the jury $;^{39}$ in proceedings to compel or stay arbitration the issue is one solely for the court.

The present policy of the courts in deciding matters which the parties presumably intended to go to arbitral tribunals impairs other basic advantages of arbitration-the savings in time and money, and the minimization of the disruptive influences of litigation where parties are in a continuing commercial relationship. 40

There is no doubt that the results reached in arbitration can differ widely from those achieved by courts of law. ${ }^{41} \mathrm{It}$ is possible that the courts are becoming alarmed at the growing schism between the law as interpreted by the judges and actual business practices as interpreted by the arbitrators. The apprehension seems justified that the courts in the commercial field are losing one of their most important functions, the channeling and rechanneling of the behavior of the

${ }^{25}$ The Court of Appeals found that the buyer was long experienced in the textile tradea fact which might lead to the conclusion that he was in fact aware of the arbitration clause in the sales note. In the light of the specific finding of fact by the court below, however, the Court of Appeals was sine juris to make a contrary finding.

${ }^{36}$ See note 32 supra. ${ }^{37}$ See text to notes 9 and 10 supra.

${ }^{38}$ Another alleged benefit which has been limited is the commercial disposition of controversies by an arbitrator equipped with special expertise in the field. Mentschikoff, The Significance of Arbitration, 17 Law \& Contemp. Prob. 698 (1952).

399 Wigmore, Evidence $\$ 2440$ (3d ed., 1940).

${ }^{10}$ Consult e.g., 63 Harv. L. Rev. 681 (1949).

4 Contrast 61 Harv. L. Rev. 1022 (1948). 
society. The judges may feel that they are in a better position than the arbitrators to consider the social impact of decisions on issues which have previously gone to arbitration. The courts may equally be worried about the inconsistent results said by some writers to exist in the arbitration world. ${ }^{2}$

Early critics of the New York arbitration statute suggested that by making the agreements irrevocable and specifically enforceable the advantages of arbitration would in time be lost. ${ }^{43}$ It may be argued that the arbitration system yields satisfactory results only if the parties voluntarily submit to arbitration. To specifically enforce arbitration agreements, and thus in effect to force the parties to arbitrate, perhaps substantially lessens the effectiveness of settling controversies without employing the cumbersome court machinery. The increasing litigation in the arbitration field may indicate that this view has merit.44

In other fields of the law the courts have been very hesitant to dismiss controversies in preliminary proceedings which, at least presumably, do not go to the merits. Thus, under the rules for striking sham, frivolous, or irrelevant pleadings, ${ }^{45}$ the New York courts have stringently limited the exercise of this discretion. In a leading case ${ }^{46}$ it was held that motions to strike irrelevant and redundant matter are not favored by the courts, and should be granted only when the irrelevancy is clear and the redundancy unquestioned. An added requirement, not found in rules governing motions to stay arbitration, is that the moving party be clearly aggrieved by the pleading in question. ${ }^{47}$ In view of these firmly established rules concerning motions to strike, the courts' present treatment of motions to compel or stay arbitration seems more nearly analogous to their treatment of motions to dismiss actions at law. While in the latter instance the courts necessarily consider the merits of the case, proceedings to stay or compel arbitration presumably do not go to the merits.

As pointed out above, the desirability of an extended system of arbitration is, at least, controversial; but in view of the very broad New York arbitration

"Consult e.g., Westwood and Howard, Self-Government in the Securities Business, 17 Law \& Contemp. Prob. 518 (1952); Isaacs, Two Views of Commercial Arbitration, 40 Harv. L.
Rev. 929 (1927); Kronstein, Business Arbitration Rev. 929 (1927); Kronstein, Business Arbitration-Instrument of Private Government, 54
Yale L. J. 36 (1944).

${ }^{13}$ E.g., Phillips, Paradox in Arbitration Law, 46 Harv. L. Rev. 1258 (1933).

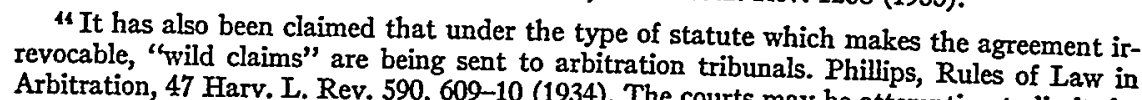
Arbitration, 47 Harv. L. Rev. 590, 609-10 (1934). The courts may be attempting to limit the
use of arbitration as a mechanism for harassment It should be nules use of arbitration as a mechanism for harassment. It should be noted, however, that, due to the much less substantial in arbitrarion than they are arbitration, possibilities of harassment are

${ }^{45} \mathrm{New}$ York Rules of Civil Practice, Rules 103, 104 (as amended, 1944).

4N Nasmic Const. Co. v. Quasman, 215 App. Div. 724, 212 N.Y.S. 391 (2d Dep't, 1925). "See also Terry v. Mars Realty Co., 224 N.Y.S. 37 (S. Ct., 1927), where the court held
that a motion to strike a denial, which neither shows bad faith nor appears to have been inter-
posed necessarily as a sham, will be refused. posed necessarily as a sham, will be refused. 
statute, it may be doubted that the courts are justified in so drastically limiting the arbitrator's function in the absence of new legislation. ${ }^{48}$

18 The Judicial Council of New York has suggested an amendment to $\$ 1448$ of the New York Civil Practice Act providing that a controversy cannot be arbitrated "when the controversy arises out of the performance of the contract and such performance has been rendered illegal or impossible by law." This suggested amendment would seem to limit by implication the power of the courts to stay arbitration despite an agreement to arbitrate to the cases specifically provided for. 17 Annual Rep., Judicial Council of New York, 225 (1951).

\section{PROPRIETY OF COMMENT ON NON-TAXABILITY OF PERSONAL INJURY VERDICTS}

Hall v. Chicago \& N.W. Ry. Co. ${ }^{1}$ raises a perplexing problem concerning the propriety of informing the jury that personal injury verdicts are not subject to federal income tax. ${ }^{2}$ Plaintiff brought suit under the Federal Employers' Liability $\mathrm{Act}^{3}$ to recover damages for permanent disability. During the trial the judge ruled in chambers that on the issue of earning capacity evidence of earnings before taxes should be presented. ${ }^{4}$ Although the trial resulted in a $\$ 50,000$ verdict for plaintiff, the trial court granted plaintiff's motion for a new trial, solely on the ground that it was prejudicial error for defendant's counsel to tell the jury that any award to the plaintiff would not be subject to federal income tax. The Illinois Appellate Court reversed and remanded the cause, with directions to reinstate the verdict.

In reaching the decision, the Appellate Court concerned itself primarily with the question of whether the defendant would be prejudiced if the jury assumed that the judgment was taxable. The court reasoned that if the jurors were not informed that the award was not taxable they might erroneously assume the contrary and increase it by an amount sufficient to offset the tax. The court concluded that it was desirable to inform the jury that the verdict would not be taxable in order to prevent such an unjustifiable windfall to the plaintiff. The court found support for its decision in a recent Missouri Supreme Court ${ }^{5}$ holding

1349 Ill. App. 175, 110 N.E. 2d 654 (1953).

2 Int. Rev. Code § 22(b)(5), 26 U.S.C.A. §22(b)(5) (1948).

345 U.S.C.A. $\$ \$ 51-60$ (1943).

4 This ruling is supported by the bulk of Anglo-American authority: Billingham v. Hughes, [1949] 1 K.B. 643, 9 A.L.R. 2d 311 (1949); Chicago \& N.W. Ry. Co. v. Curl, 178 F. 2d 497 (C,A. 8th, 1949); Stokes v. United States, 144 F. 2d 82 (C.A. 2d, 1944); Smith v. Pa. R. Co., 99 N.E. 2d 501 (1950). These cases hold that the trial court's refusal to allow evidence of plaintiff's net income after tax deductions was not reversible error, principally because such deductions are too conjectural and would involve insuperable difficulties in estimating the amount of income tax which the injured person would be liable to pay on his future earnings because of dependencies, outside income, and other considerations. But cf. De Vito v. United Airlines, 98 F. Supp. 88 (1951).

${ }^{5}$ Dempsey v. Thompson, - Mo. - 251 S.W. $2 \mathrm{~d} 42$ (1953), overruling Hilton v. Thompson, 360 Mo. 177, 227 S.W. 2 d 675 (1950). Criticizing Dempsey v. Thompson, see 33 B.U.I. Rev. 114 (1953), 32 Neb. L. Rev. 491 (1953). 